\title{
WIND TUNNEL TESTS OF INFLUENCE OF BOOSTERS AND FINS ON AERODYNAMIC CHARACTERISTICS OF THE EXPERIMENTAL ROCKET PLATFORM
}

\author{
Pawel Ruchala, Robert Placek, Wit Stryczniewicz, Jan Matyszewski, \\ DAWID CIEŚLIŃSKI, BARTOSZ BARTKOWIAK \\ Institute of Aviation, al. Krakowska 110/114, 02-256 Warsaw, Poland \\ pawel.ruchala@ilot.edu.pl, robert.placek@ilot.edu.pl,wit.stryczniewicz@ilot.edu.pl,jan.matyszewski@ilot.edu.pl, \\ dawid.cieslinski@ilot.edu.pl, bartosz.bartkowiak@ilot.edu.pl
}

\begin{abstract}
The paper presents results of wind tunnel tests of the Experimental Rocket Platform (ERP), which is developed in Institute of Aviation. It is designed as an easy accessible and affordable platform for microgravity experiments. Proposed design enables to perform experiments in microgravity for almost 150 seconds with apogee of about $100 \mathrm{~km}$.

The full-scale model of the ERP has been investigated in the T-3 wind tunnel in Institute of Aviation. During the investigation, the aerodynamic loads of the rocket has been measured for the angle of attack up to $10^{\circ}$ and the different rotation angle around the longitudinal axis (up to $90^{\circ}$, depending on the configuration). Three configurations has been investigated:

- without fins and boosters

- with fins and without boosters

- with fins and boosters

Additionally, the measurements of velocity field around the ERP using the Particle Image Velocimetry (PIV) has been performed.

Based on the wind tunnel test, an influence of fins and boosters on aerodynamic characteristics of the rocket has been described. Results of the wind tunnel tests show relatively high contribution of boosters in total aerodynamic drag. Some conclusions concerning performance and stability of the rocket have been presented.
\end{abstract}

Keywords: Aerodynamics of rocket, flight mechanics of rocket, wind tunnel tests, experimental, rocket, platform, ERP, sounding rocket. 


\section{INTRODUCTION}

The Experimental Rocket Platform (ERP) (Figure 1) is a project realized by the Space Technology Department at the Institute of Aviation in Warsaw [1]. Its main goal is to demonstrate the possibilities of launching a $5 \mathrm{~kg}$ of payload to slightly above $100 \mathrm{~km}$ in height (Kármán's line) and recover safely. During the flight, $150 \mathrm{~s}$ of a low gravity state (below $0.001 \mathrm{~g}$ ) will be achieved. The project is connected to the history of a polish technical idea - Meteor sounding rocket program, developed in the 60' and 70' at Institute of Aviation [2-5].

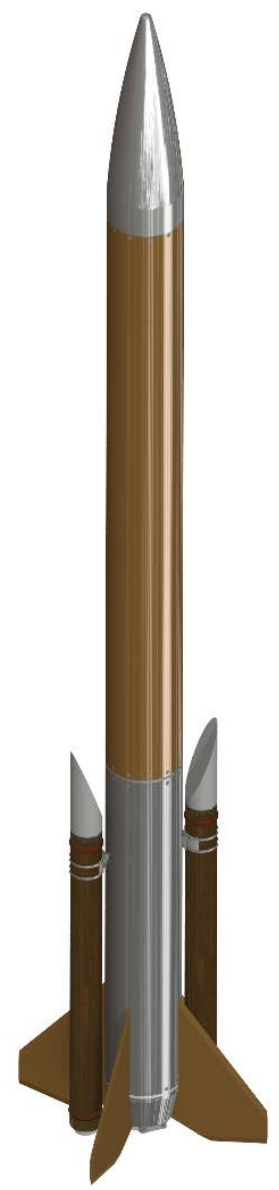

Figure 1. ERP model.

The ERP is an unguided, two-staged, sounding rocket that is stabilized aerodynamically. Its main stage is powered by a hybrid rocket motor using high-test peroxide (HTP 98\%) as an oxidizer. The rocket launch is supported by two solid-propellant boosters started in parallel with the main stage engine, and then aerodynamically separated after their burnout [6]. 
The rocket is equipped with an on-board flight computer that registers flight parameters and controls the assumed mission profile. The flight computer and the payload case are recoverable parts of the construction. The rocket is slightly more than $4.0 \mathrm{~m}$ in length and about $175 \mathrm{~kg}$ of take-off weight. The boosters are about $1.2 \mathrm{~m}$ in length.

During the work on the project there was a need to define rocket aerodynamic characteristics in the low flight velocity range (especially aerodynamic normal forces and moments). Knowledge of these gives a possibility of designing stable construction and guarantees safe and controlled flight $[7,8]$. The non-standard shape of the rocket caused carrying out a wind tunnel investigation. Additionally, the wind tunnel tests bring enhancement of rocket flight performance thanks to static margin decrease and a better choice of launch parameters. It will be also possible to compare results of wind tunnel tests with the CFD simulation.

Based on wind tunnel investigation results, the influence of rocket parts (such as body, boosters and fins) on aerodynamic characteristics was determined. This knowledge is necessary to develop an analytical model of the rocket aerodynamics, essential to determine characteristics while some modifications of the construction shape are done. Additionally, measurements of the velocity field around the rocket from Particle Image Velocimetry (PIV) gave a possibility of evaluating the operation of the aerodynamic separating system.

\section{WIND TUNNEL TESTS}

\subsection{State of the art}

Despite of having numerical tools (still being developed) for fluid dynamics simulations, wind tunnel investigations are still an attractive method for aerodynamic performance calculations of the rockets and missiles. It is caused by the fact that the numerical computations results may lead to specific inaccuracies, e.g. in drag force prediction (turbulence model choice) [9] when precise characteristics are desired. Wind tunnel tests are valuable in situations, where any complex configuration, e.g. various heads shapes preliminary chosen by CFD computations [10] or specific interaction, e.g. lateral jets [11] or transient responses for manuevers [12] appear. For such situations experimental investigation is used to numerical model calibration and for a satisfactory agreement between model and tests' results the simulations can be then treated as a good design and qualitative approach. Wind tunnel investigation is commonly applied for rocket configurations that include boosters, such as NASA's Space Launch System [13] or Space Transportation System's Shuttle [14] because of the aerodynamic interaction phenomena between the main body (shuttle) and boosters/tanks. For those applications precise determination of the aerodynamic performances were even more important, because those are manned space vehicles.

What is worth pointing out, the first supersonic sounding rockets aiming at the ceilings over $80 \mathrm{~km}$ designed by Institute of Aviation were also tested in trisonic wind tunnel in 1960s. 


\subsection{Test stand}

The ERP model was tested in the T-3 wind tunnel of Institute of Aviation. The T- 3 wind tunnel is an atmospheric, close circuit and open test section type. The test section diameter is $5 \mathrm{~m}$ and length is $6.5 \mathrm{~m}$. The airflow speed can be changed continuously from $3.2 \mathrm{~m} / \mathrm{s}$ up to $90 \mathrm{~m} / \mathrm{s}$. The infrastructure of the T-3 wind tunnel gives a possibility to change the orientation of model in two planes. The angle of attack can be changed in range from $-40^{\circ}$ up to $45^{\circ}$ and the sideslip angle in range from $-180^{\circ}$ up to $180^{\circ}$. The scheme of wind tunnel is presented on Figure 2. [15]

During research the 6-component AEROTECH-0463 strain gauge balance was used. For each model position in the test section three components of force and three component of moment were measured. Based on measured values, the aerodynamic coefficients were calculated. Simultaneously, the cavity pressure from the rocket nozzle and pressure from base area were registered by ESP type sensors. It allowed to calculate axial force, which would act on the bottom part of the rocket model, covered by the sting. This force has been subtracted, because the investigation included the active mode (i.e. when nozzle area is neglected).

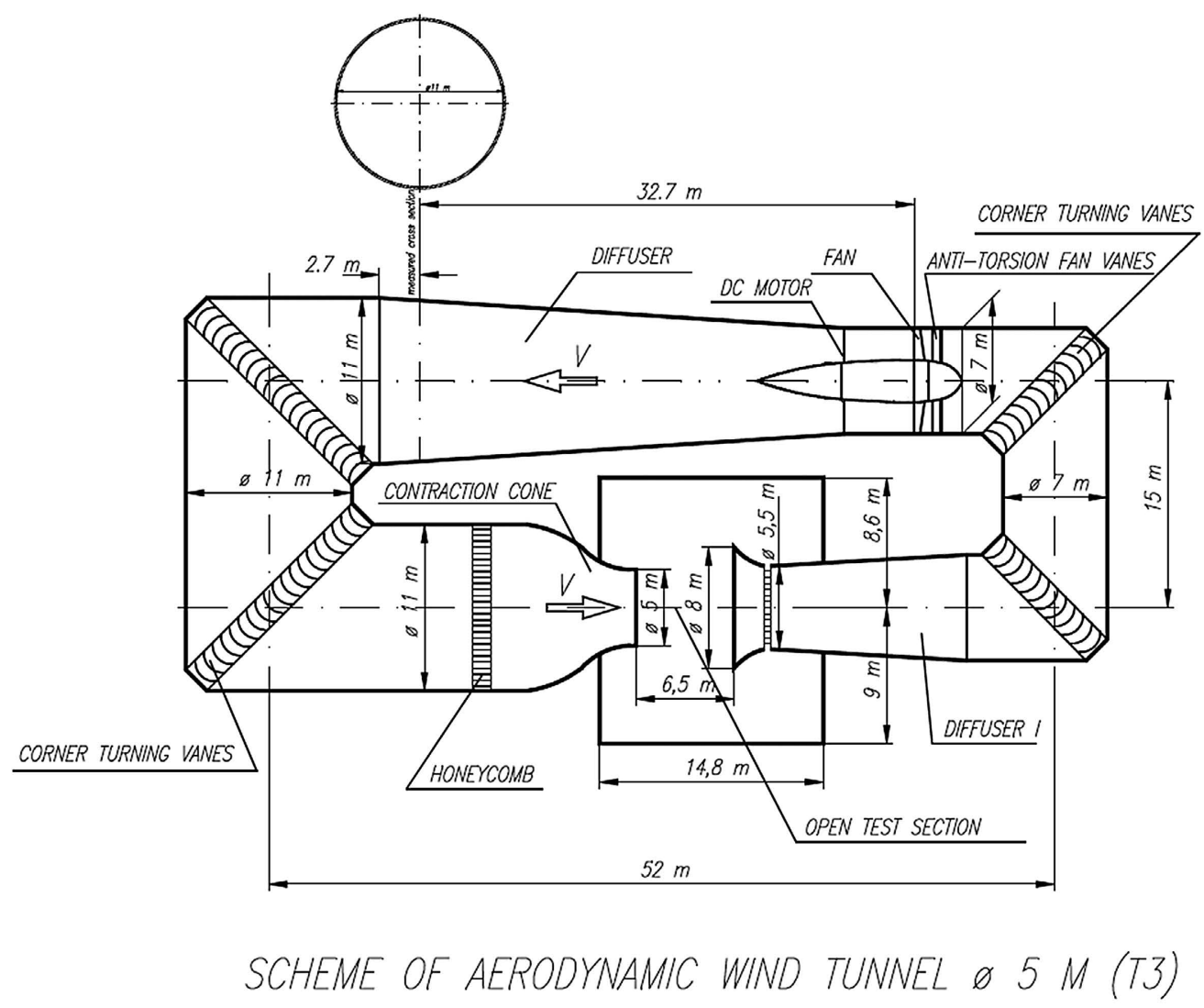

Figure 2. Scheme of the T-3 wind tunnel. 
Additionally, the velocity field around the nose of upper booster was investigated with the PIV (Particle Image Velocimetry) method. The PIV is a modern technique of measurement and visualization of the flow velocity field $[16,17]$. To make the measurement, seeding particles (the DEHC oil in this case) must be atomized in the flow. Droplets of the seeding are illuminated with lightsheet (i.e. a laser light, formed in a thin sheet by the lenses) and photographed by a camera. The diameter of a seeding droplet is a few microns. For every measurement the camera grabs two frames. The time interval between frames in presented measurements was $\Delta \mathrm{t}=30 \mu \mathrm{s}$. In the post-processing phase the measured velocity field is obtained by determination of the particles displacements (Adaptive Correlation scheme, with integration windows size of $64 \times 64$ pixels with $50 \%$ window overlap). The displacements are divided by the time interval $\Delta \mathrm{t}$ to calculate the velocity field. The outlier vectors and missing data was removed in post-processing with the use of average and median filtering [18].

\subsection{Model}

To conduct the wind tunnel test, a full-scale rocket model was created. The significant aerodynamic dimensions are presented on the Figure 3. The body of the main stage, fins, and boosters' noses were made from aluminum alloys. The main stage's nose and boosters' body were made of fiberglass- epoxy composite. The abovementioned materials give a compromise between model weight and ease of component processing. To investigate different rocket configurations, there was a possibility to disassemble the fins and boosters.

The investigated full-scale model was held down on the horizontal straight sting in the test section (Figure 4). The location of the balance center was chosen to make it close to the model's center of mass in all the possible configurations. It was important because of the mass force moment reduction.
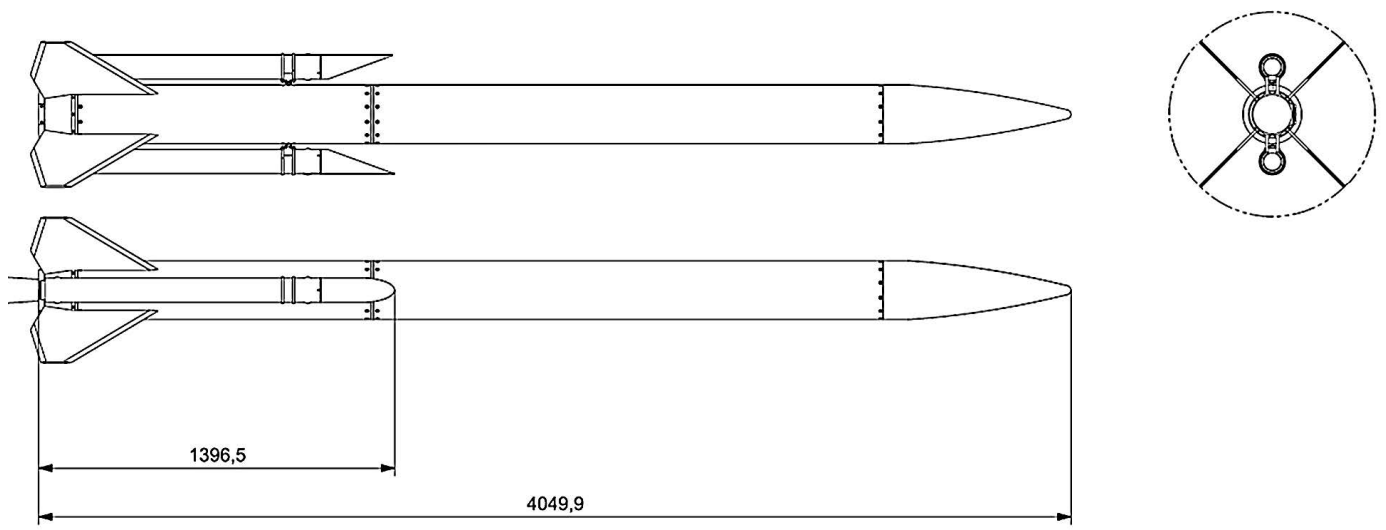

Figure 3. The significant aerodynamic dimensions of the model. 


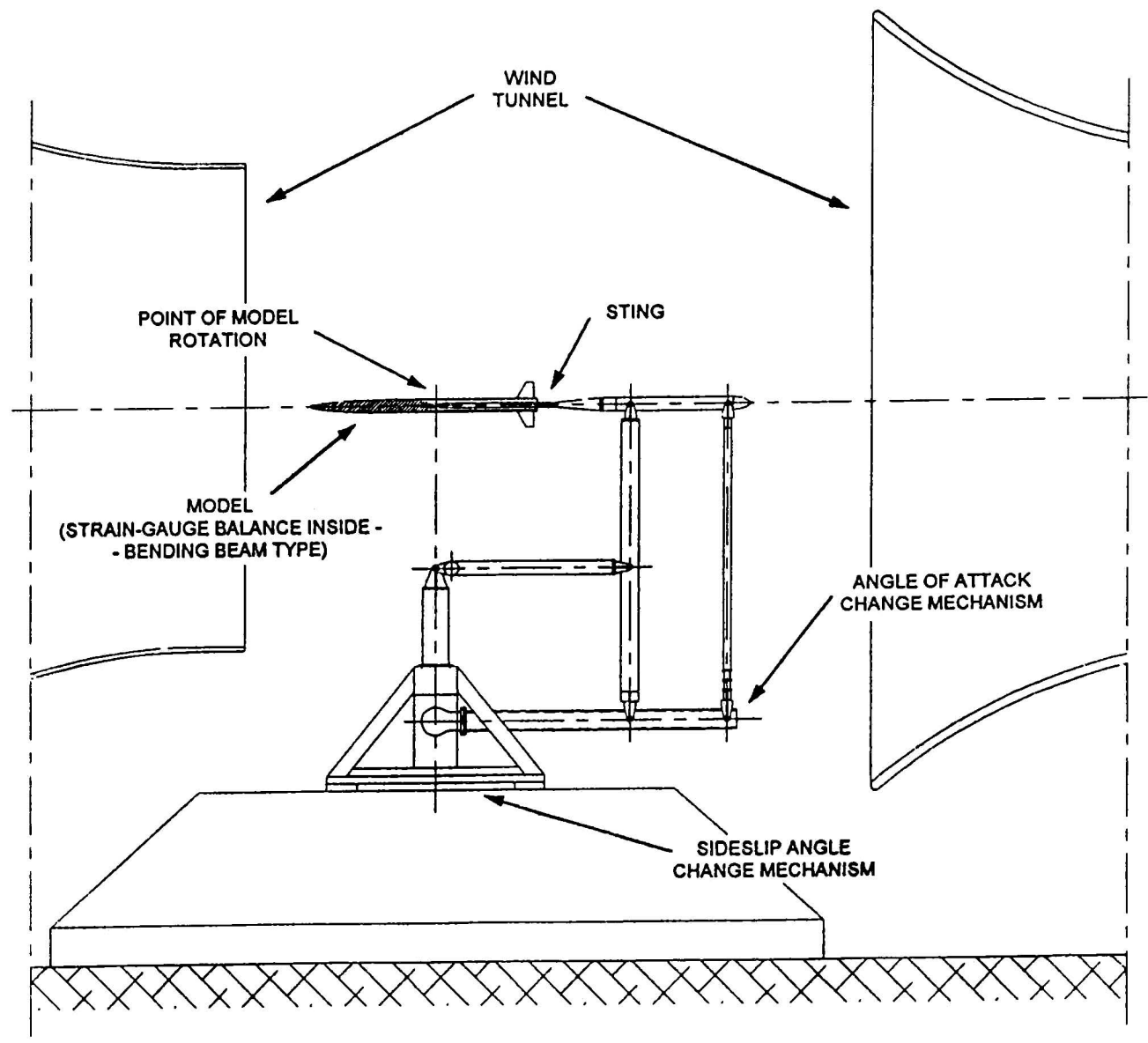

Figure 4. Scheme of the test stand.

\subsection{Coordinate systems}

The analyses of the wind tunnel investigation results were carried out in the following coordinate systems (Figure 5):

- $\mathrm{Ox}_{\mathrm{T}} \mathrm{y}_{\mathrm{T}} \mathrm{z}_{\mathrm{T}}$ - wind-tunnel airflow coordinate system

- Oxyz - airflow coordinate system

- $\mathrm{Ox}_{\mathrm{M}} \mathrm{y}_{\mathrm{M}} \mathrm{z}_{\mathrm{M}}-$ model coordinate system

The airflow coordinate system does not change the orientation towards a non-disturbed airflow stream. The model-coordinate system does not change the orientation towards rocket model.

$\mathrm{Ox}_{\mathrm{T}} \mathrm{y}_{\mathrm{T}} \mathrm{z}_{\mathrm{T}}$ is the wind-tunnel airflow coordinate system defined by non-disturbed airflow and two base model rotation axes. The rotation of the tunnel sideslip angle $\beta$ is carried out by rotating the model around the $\mathrm{Oz}_{\mathrm{T}}$ axis. The rotation of the tunnel angle of attack $\alpha$ is carried out by rotating the model around the $\mathrm{Oy}_{\mathrm{T}}$ axis after the rotation of the tunnel sideslip angle. 


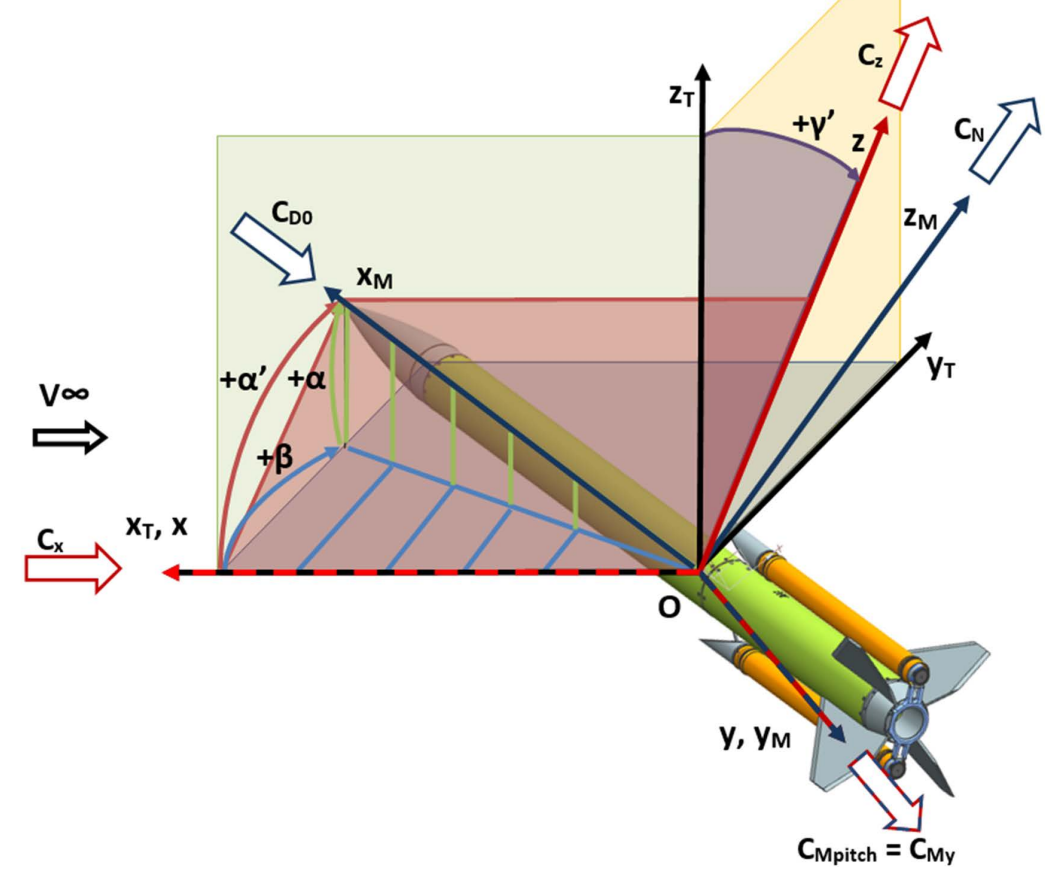

Figure 5. The coordinate systems of the ERP model in the wind tunnel.

The presentation of the analyzed results and the investigation program was set out in the model and airflow coordinate system. This additionally defined coordinate systems are rotated by a roll angle $\gamma^{\prime}$ towards the $\mathrm{Ox}_{\mathrm{T}}$ axis of the wind-tunnel coordinate system in such the way that the $\mathrm{Ox}, \mathrm{Oz}, \mathrm{Ox}_{\mathrm{M}}$ and $\mathrm{Oz}_{\mathrm{M}}$ axes coincides with the deflection plane. The deflection plane is defined by $\mathrm{Ox}_{\mathrm{T}}$ axis before rotations and $\mathrm{Ox}_{\mathrm{M}}$ axis after rotations of the tunnel sideslip angle and angle of attack. The angle between these axes is in the real the angle between the longitudinal rocket axis and the non-disturbed airflow velocity vector and was named as the real angle of attack $\left(\alpha^{\prime}\right)$. The direct relationship between the angles, $\alpha^{\prime}$ and $\gamma^{\prime}$, and the tunnel angles, $\alpha$ and $\beta$, can be set based on the rotation matrix [19]. Because of the fact that the tests' results were presented in model and airflow coordinate system and they are always related to the angles $\alpha$ ' and $\gamma^{\prime}$, in the further parts of this paper the real angle of attack was simply named as the angle of attack.

The aerodynamic moments were calculated towards the assumed center of gravity of ERP, which is located $1.64 \mathrm{~m}$ from the bottom of rocket towards the head of the rocket. The rocket diameter was taken as the characteristic dimension. The reference area used in aerodynamic coefficients calculation, for every configuration, was the rocket body cross section area. 


\subsection{Investigation program}

The investigation was conducted in 3 configurations:

- Body

- Body \& fins

- Body, fins \& boosters (also named as the full configuration).

The airflow speed during the test was $60 \mathrm{~m} / \mathrm{s}$. The Reynolds number referred to the model diameter was about $1.2 \cdot 10^{6}$. The aerodynamic forces was measured discretely, based on the set of measurement points, which were defined for each configuration individually.

The aerodynamic forces as a function of the angle of attack $\alpha^{\prime}$ were measured in ten angles $\left(0.5^{\circ}, 1^{\circ}, 1.5^{\circ}, 2^{\circ}, 3^{\circ}, 4^{\circ}, 5^{\circ}, 6^{\circ}, 8^{\circ}, 10^{\circ}\right)$, for the following roll angles:

- $\quad$ Body $-\gamma^{\prime}=0^{\circ}$

- Body \& fins $-\gamma^{\prime}=0^{\circ} / 90^{\circ}$

- Body, fins \& boosters $-\gamma^{\prime}=0^{\circ}$ and $\gamma^{\prime}=90^{\circ}$ (Figure 6)

Additionally, for the full configuration, the all angles of attack and 0 degrees of the roll angle, the velocity field around the boosters nose was measured using the PIV.

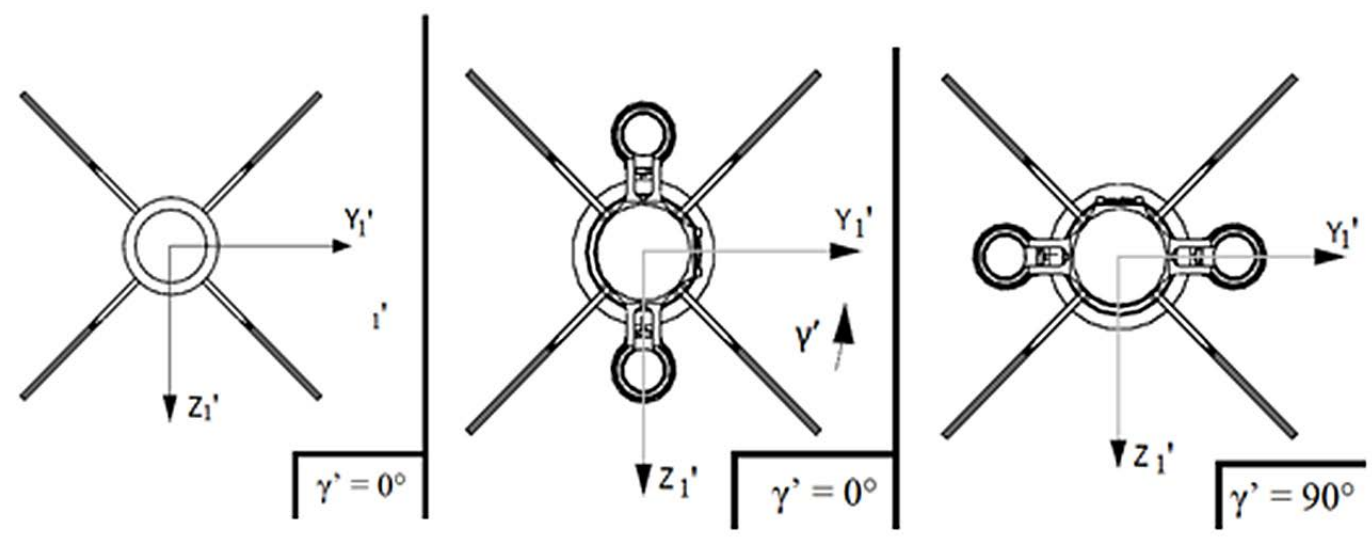

Figure 6. The roll angles.

\section{RESULTS OF WIND TUNNEL TESTS}

\subsection{Axial force and drag coefficient}

In Figure 7 the axial force coefficient $\mathrm{C}_{\mathrm{D} 0}$ versus angle of attack $\alpha$ ' for all investigated configurations has been presented. It can be observed that for the isolated body, the axial force coefficient increases slightly with the angle of attack increment - from 0.24 to 0.27 . Adding the fins results with increment of the axial force coefficient for $\alpha^{6}=0.5^{\circ}$ to the value of 0.28 . However, in this configuration the axial 


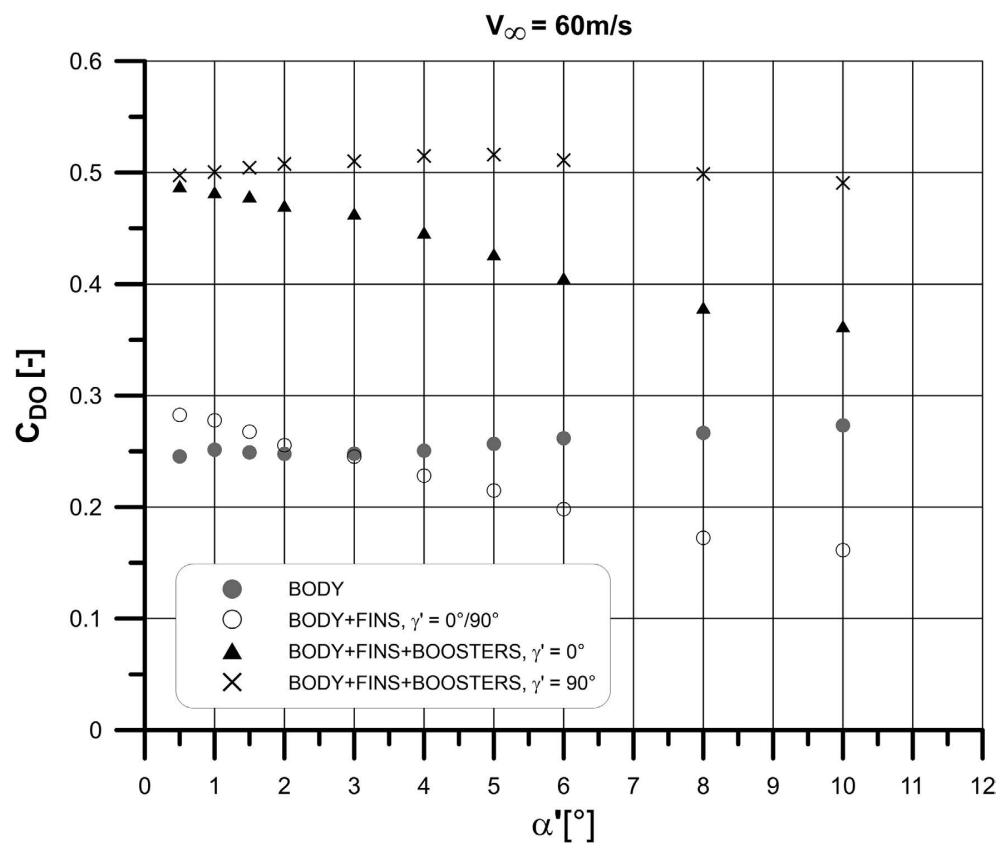

Figure 7. Axial force coefficient versus angle of attack for various configurations.

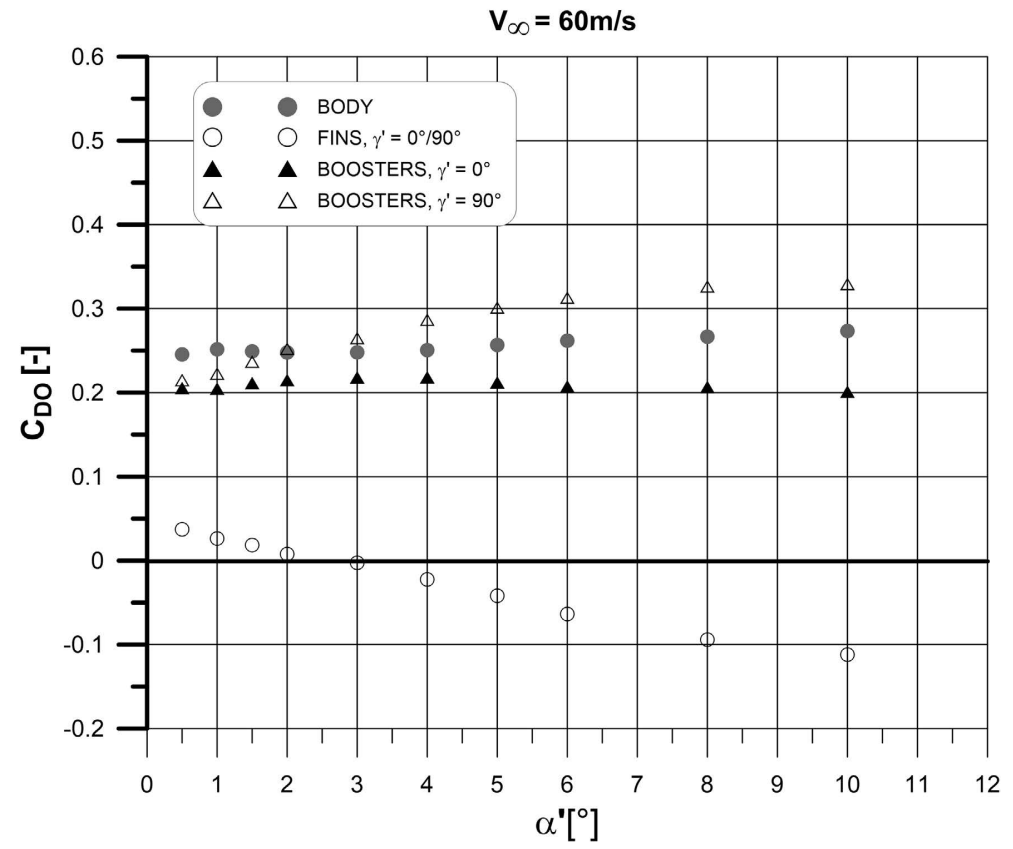

Figure 8. Axial force coefficient versus angle of attack for elements of the rocket. 


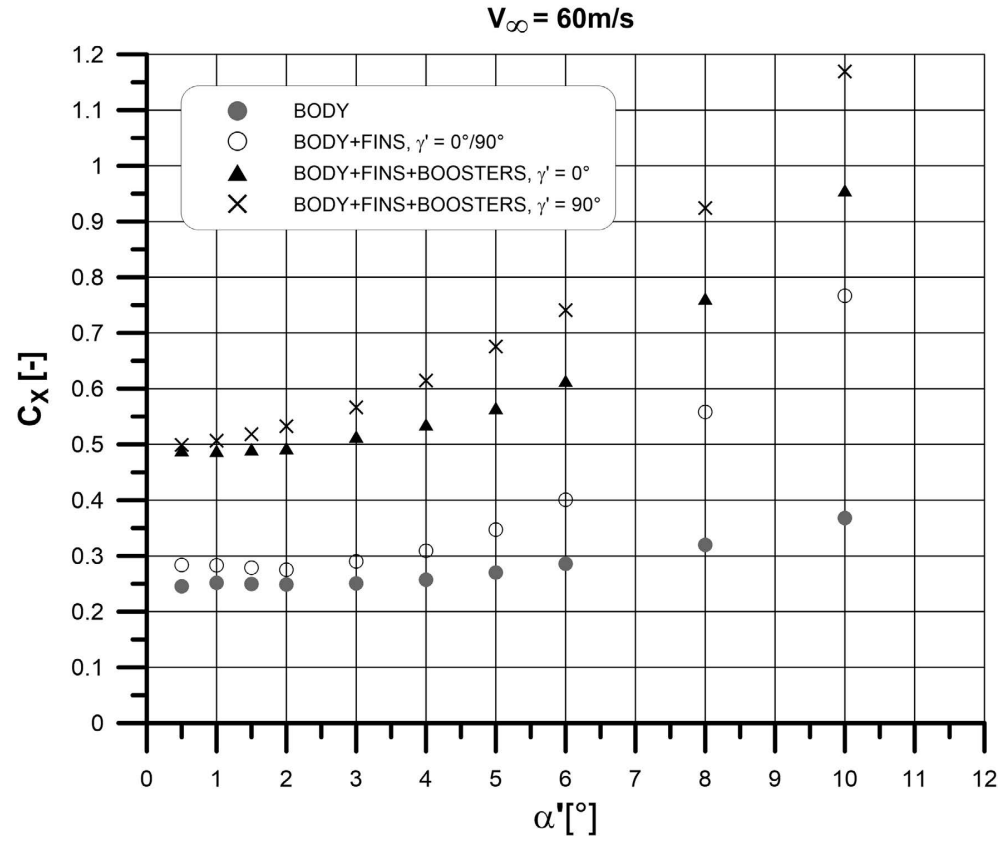

Figure 9. Drag coefficient versus angle of attack for various configurations.

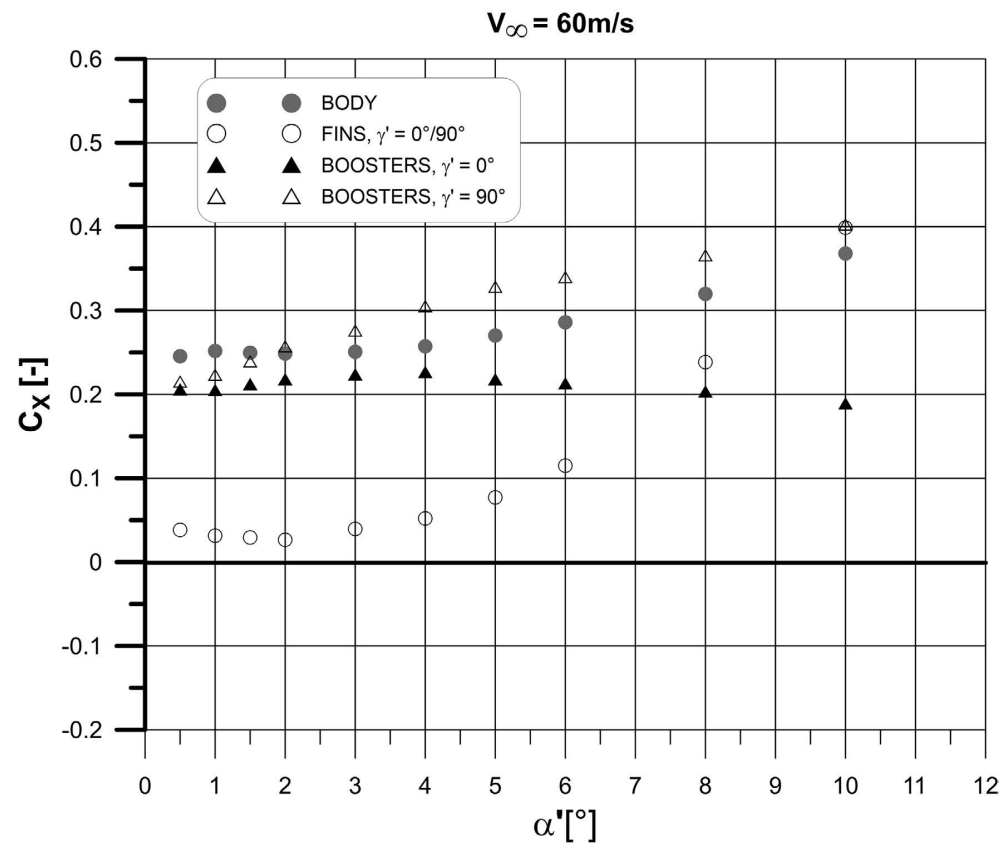

Figure 10. Drag coefficient versus angle of attack for elements of the rocket. 
force decreases significantly when the angle of attack increases. It is a result of the axial component of lift generated by the fins. A similar effect may be observed for the rocket with fins and boosters, for the roll angle of $0^{\circ}$. In this case, when the boosters lie in the deflection plane, the axial force coefficient decreases similarly, like for the rocket with fins and without boosters. Meanwhile, for the roll angle of $90^{\circ}$, when the deflection plane is perpendicular to the boosters plane, the axial force coefficient is nearly constant. This effect is also depicted in Figure 8, which plots the axial force coefficient against angle of attack for all considered elements of the rocket individually (but including an aerodynamic interference). A reason of this effect is an interference between boosters, fins and body. For $\gamma^{\prime}=90^{\circ}$ the body does not affect the flow around the boosters in a qualitative way, so one can expect that increment of the angle of attack results with enhancement of drag and enhancement of lift - see chapter 3.2. Axial components of lift increment and drag increment counteracts each other. Meanwhile for $\gamma^{\prime}=0$ the body is located in a wake of the lower booster, and the upper booster - in the wake of body. Thus increment of the angle of attack will not cause a large increment of drag and lift.

It must be noted that this consideration includes an effect of the angle of attack. In Figure 7 it is clearly visible that the axial force coefficient for the rocket with fins and boosters is relatively high and it is equal to about 0.49 for $\alpha^{6}$ close to 0 . As shown in Figure 8, the axial force coefficient for boosters and body for symmetric flight are similar ( 0.21 and 0.24 respectively), despite the boosters have smaller diameter and length than the body. In other words, drag coefficient of the booster related to its cross-section area is significantly greater than for the body, and it is equal to 0.53 . It is caused i.a. by a shape of front part of the booster, which cause a large reduction of the airflow speed in front of the booster. It can be observed on the PIV measurement results (chapter 3.5). The enhancement of aerodynamic drag is also a result of a flat bottom of each booster, instead of exhaust nozzles, and the struts joining boosters and body.

It must be underlined that results presented in Figure 7 and Figure 8 are presented in the model-coordinate system $\left(C_{D 0}\right.$ direction is parallel to the axis of rocket). The drag coefficient $C_{X}$, which is parallel to the free stream velocity, has been presented in Figure 9 and Figure 10. In these figures characteristics of $\mathrm{C}_{\mathrm{X}}$ versus angle of attack $\alpha^{6}$ have been plotted for various configurations and for various elements, respectively.

One can observe that all plots in Figure 9 have similar shape - unlike plots of axial force coefficient $\mathrm{C}_{\mathrm{D} 0}$. It confirms that the differences of axial force for various configurations are related to differences in lift force.

It also should be mentioned that the interference between body and boosters (for roll angle of 0 ), mentioned above, is visible clearly in Figure 10: for angle of attack over $4^{\circ}$ the drag of boosters decreases

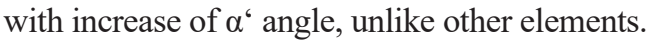

\subsection{Normal force and lift coefficient}

In Figure 11 the normal force coefficient $\mathrm{C}_{\mathrm{N}}$ versus angle of attack $\alpha^{6}$ for all investigated configurations has been presented. It can be observed that most of the normal force is generated by the fins - adding them to the body increased the total normal force coefficient 6 times (from 0.58 to 3.51 for $\alpha^{6}=10^{\circ}$ ). Adding the boosters causes further increment of normal force, up to 3.97 for $\alpha^{6}=10^{\circ}$ 
- but only for the roll angle of $90^{\circ}$. In this case, the boosters are placed on both sides of the body, thus the width of the rocket is increased. As a result, a flow around the rocket, which suppresses the normal force, is reduced. For the roll angle of $0^{\circ}$, boosters are located on top and bottom of the body and this effect does not appear.

Figure 12 illustrates the normal force coefficient $C_{N}$ versus angle of attack $\alpha$ ' for the body and for fins. It should be noted that normal force acting on the fins is about 6 times greater that the one acting on the body or the boosters. Shape of $C_{N}\left(\alpha^{6}\right)$ curve for isolated fins is nearly linear in investigated range of angles - the stall does not appears.

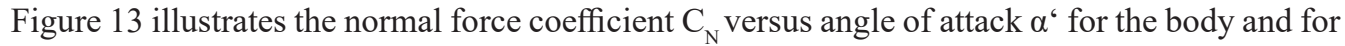
boosters. One can observe that the $\mathrm{C}_{\mathrm{N}}\left(\alpha^{6}\right)$ plot for the boosters has a local maximum for the angle of attack value of $4^{\circ} \div 5^{\circ}$, depending on the roll angle. This is probably caused by the fact that the upper vertical fin is located in a wake behind the boosters. The wake reduces local speed of the airflow around the fin, which causes reduction of lift and drag acting on it.

Lift coefficient $\mathrm{C}_{\mathrm{Z}}$ as a function of angle of attack $\alpha^{6}$ has been presented in Figure 14 (for complete rocket in various configurations) and in Figure 15 and Figure 16 (for separate elements of rocket). One can observe that the difference between $\mathrm{C}_{\mathrm{Z}}$ and $\mathrm{C}_{\mathrm{N}}$ (i.e. between forces in model coordinate system and airflow coordinate system) is negligible. It may be explained based on the equation:

$C_{Z}=C_{N} \cdot \cos \alpha^{\prime}-C_{D 0} \cdot \sin \alpha^{\prime}$

In investigated range of angle of attack values $\left(\alpha^{6} \leq 10^{\circ}\right) \mathrm{C}_{\mathrm{D} 0} \cdot \sin \alpha^{\natural}$ are significantly less than $\mathrm{C}_{\mathrm{N}}$ and $\cos \alpha^{6} \approx 1$, so $\mathrm{C}_{\mathrm{Z}} \approx \mathrm{C}_{\mathrm{N}}$.

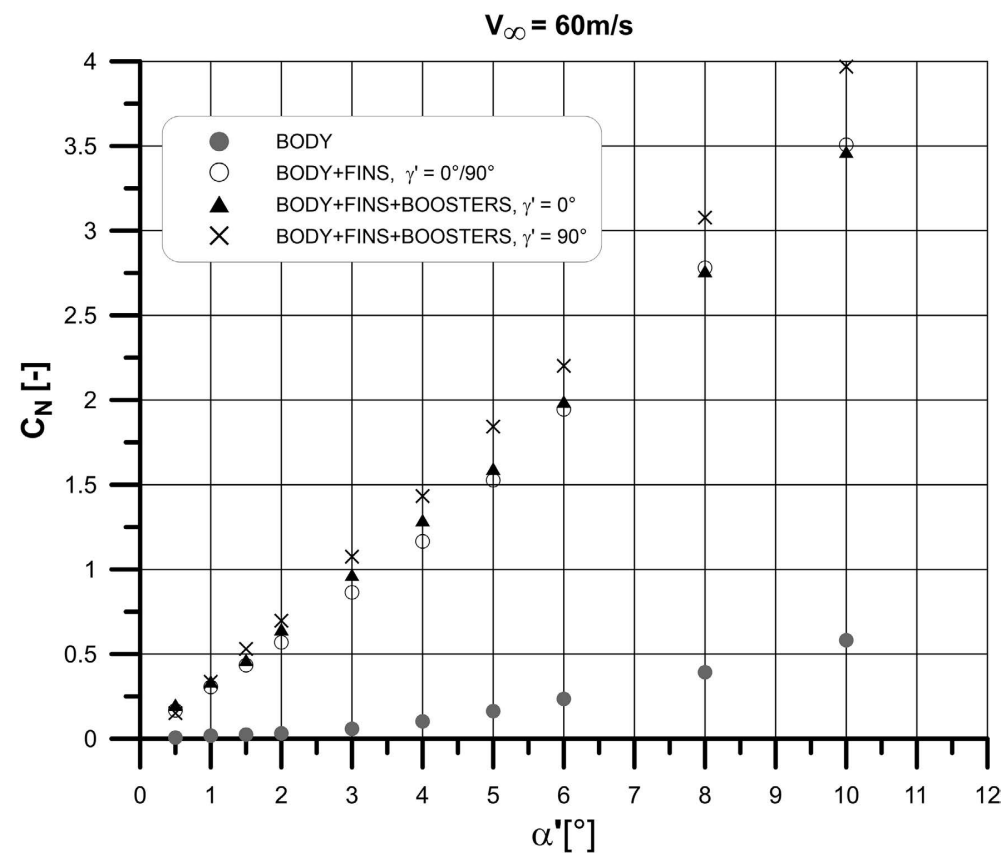

Figure 11. Normal force coefficient versus angle of attack for various configurations. 


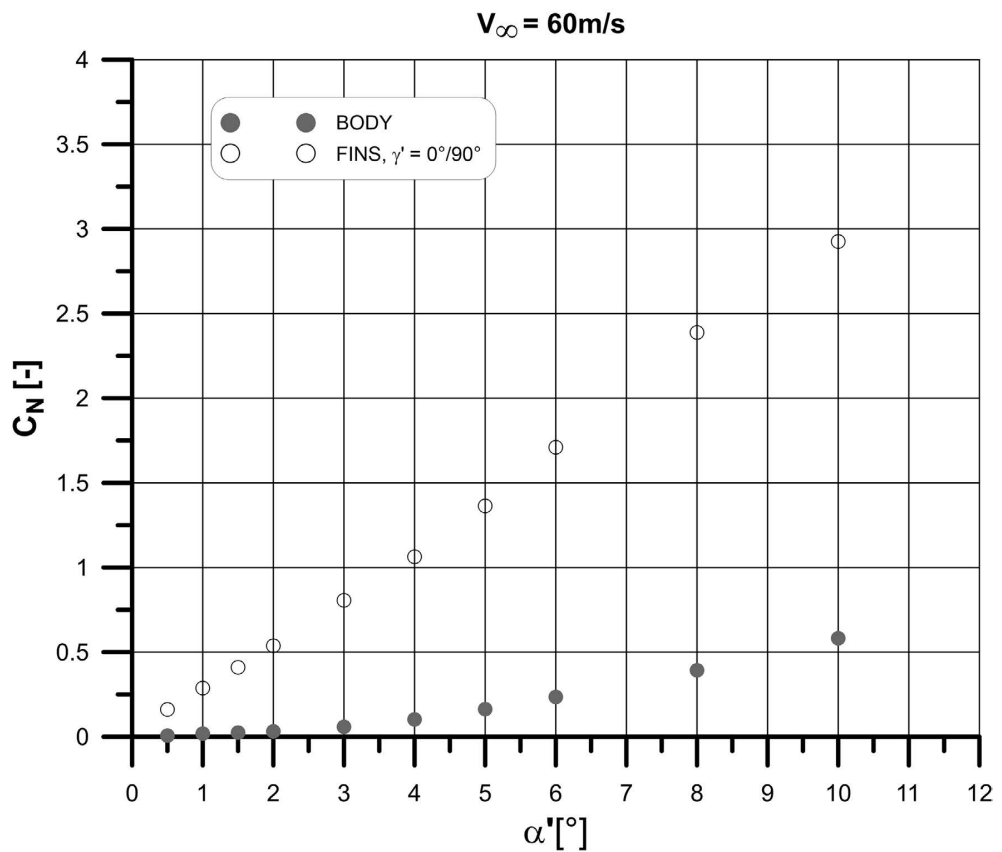

Figure 12. Normal force coefficient versus angle of attack for body and fins.

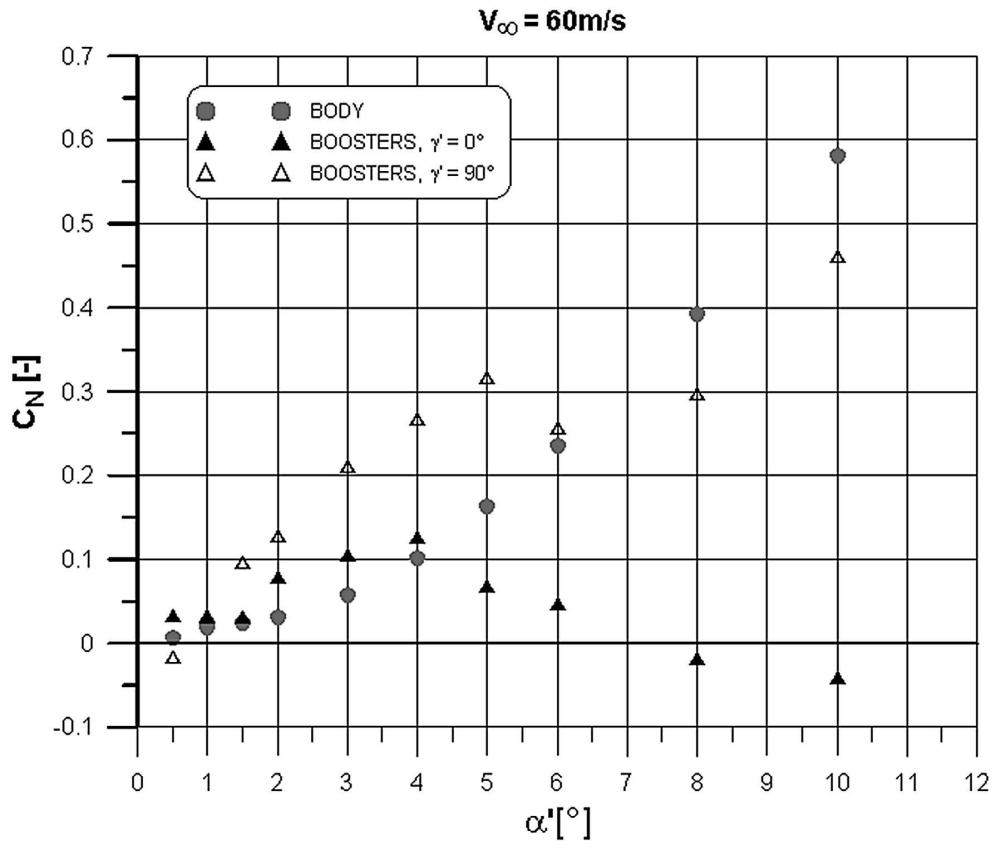

Figure 13. Normal force coefficient versus angle of attack for body and boosters. 


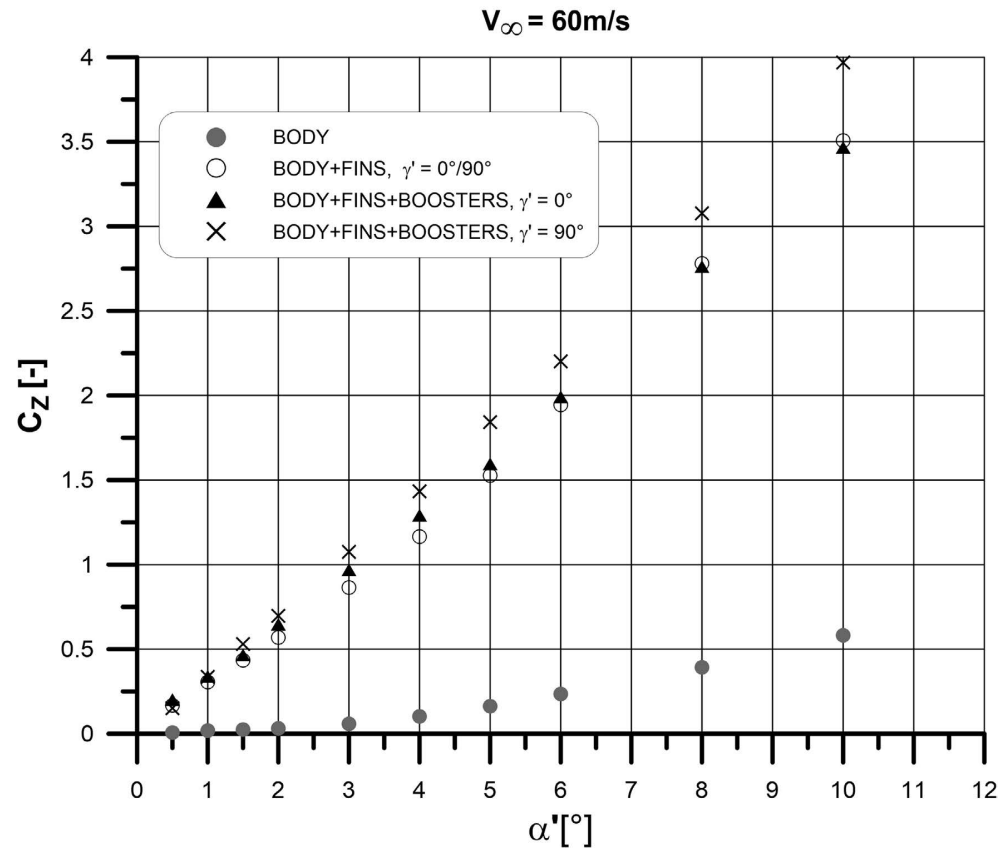

Figure 14. Lift coefficient versus angle of attack for various configurations.

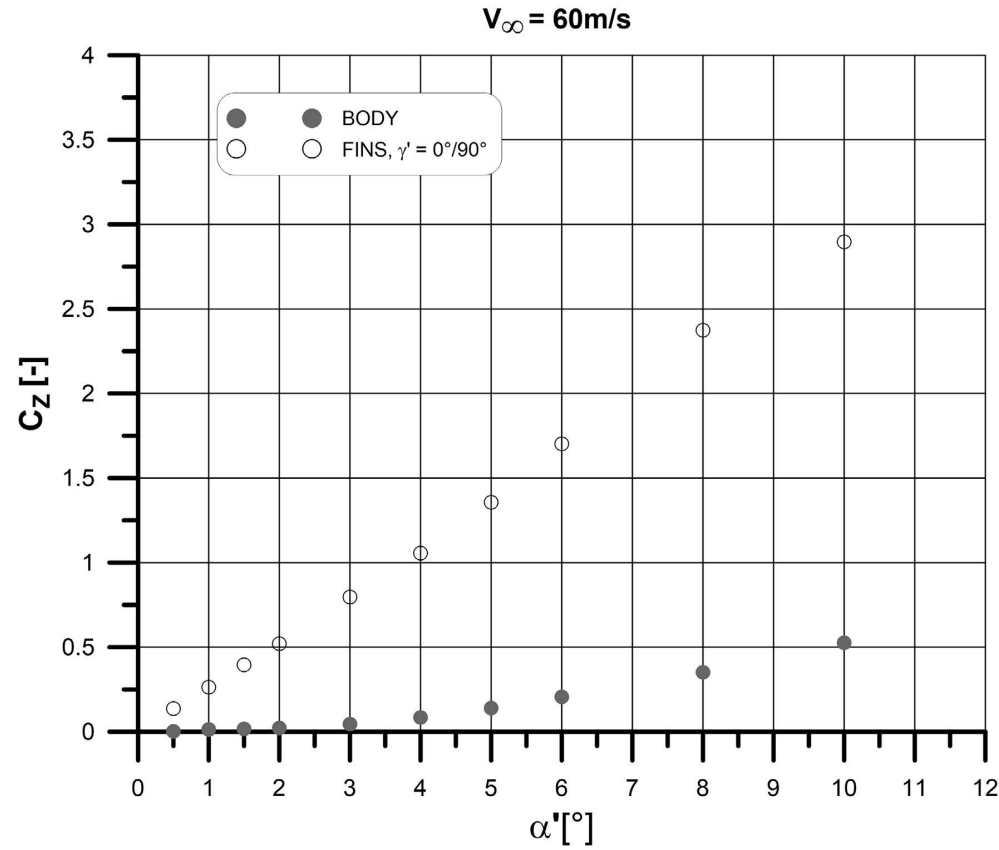

Figure 15. Lift coefficient versus angle of attack for body and fins. 


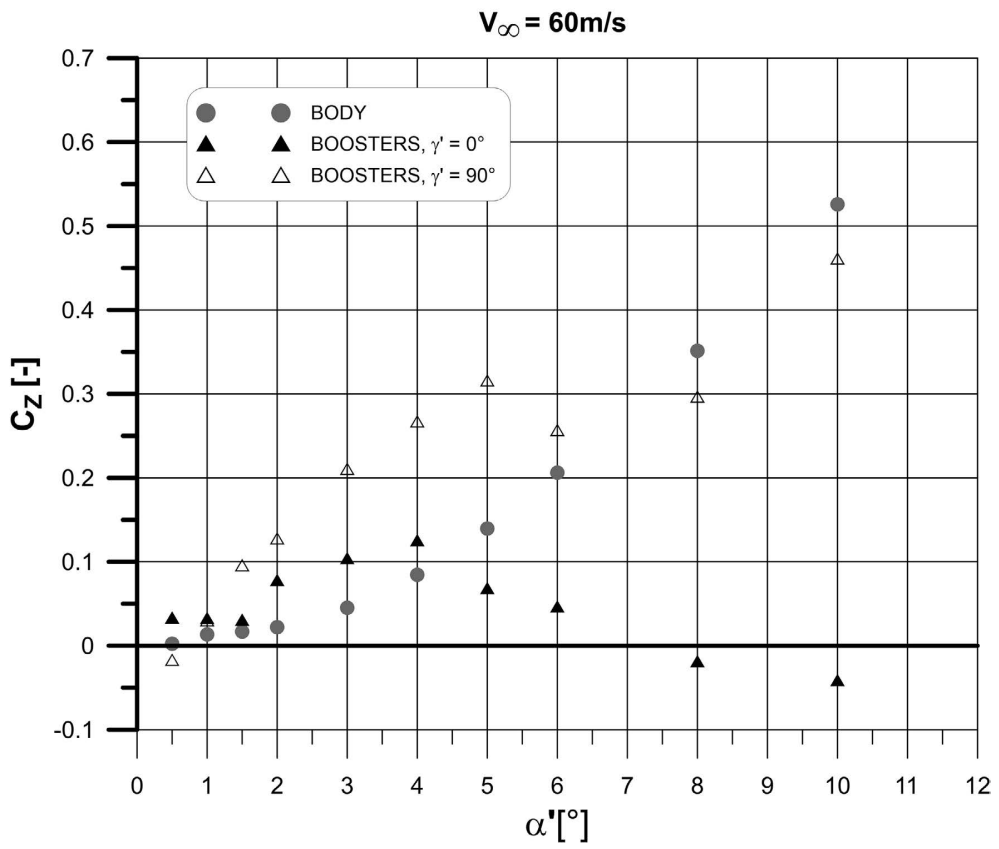

Figure 16. Lift coefficient versus angle of attack for body and boosters.

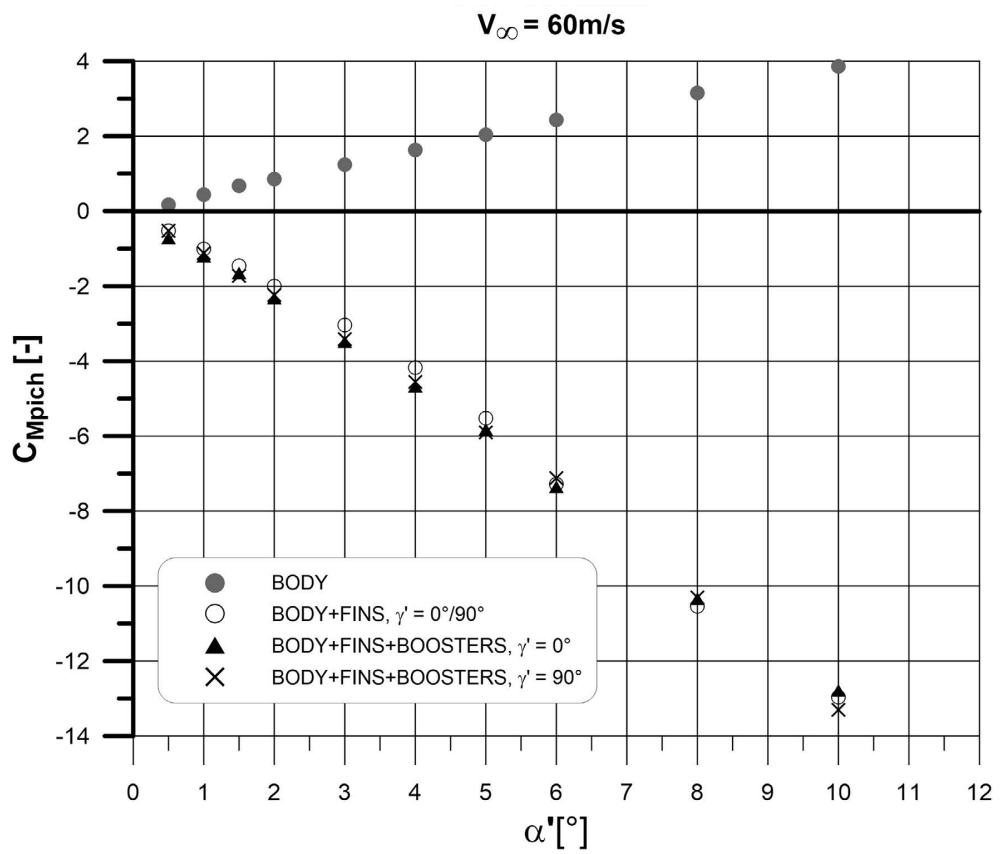

Figure 17. Pitching moment coefficient versus angle of attack for various configurations. 


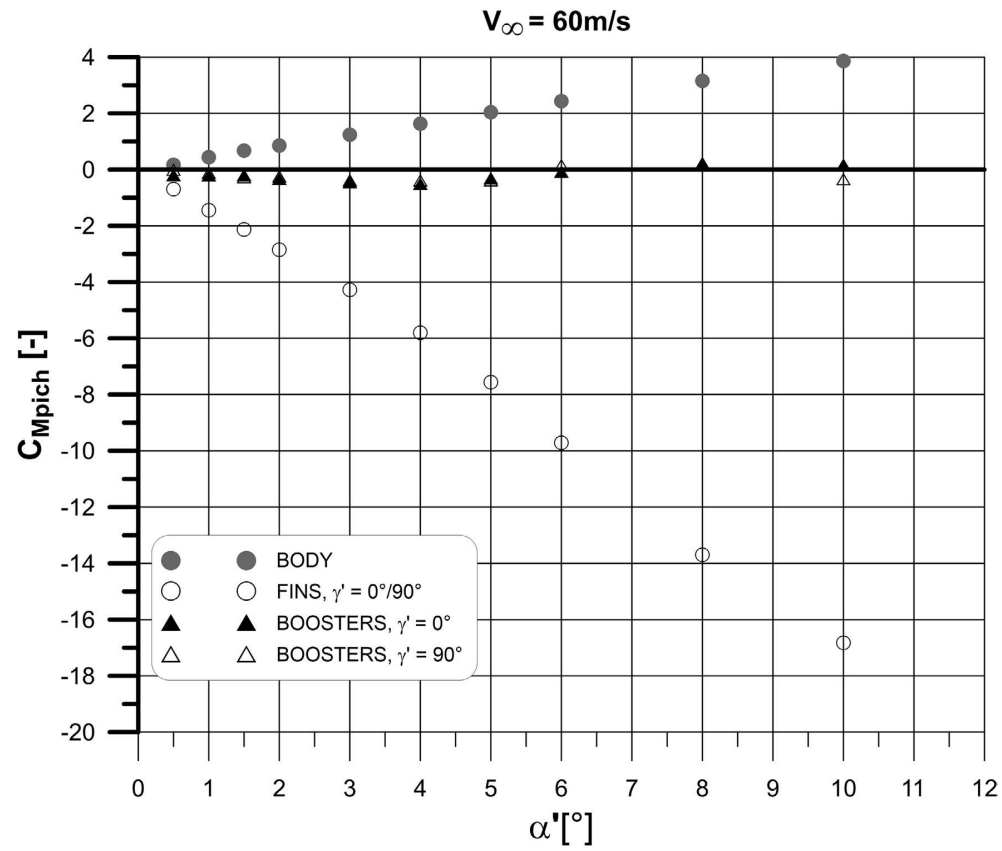

Figure 18. Pitching moment coefficient versus angle of attack for elements of the rocket.

\subsection{Pitching moment coefficient}

In Figure 17 the pitching moment coefficient $\mathrm{C}_{\text {Mpitch }}$ versus angle of attack $\alpha^{6}$ for all investigated configurations has been depicted. The longitudinal non-stability of the body $\left(\mathrm{dC}_{\mathrm{Mpitch}} / \mathrm{d} \alpha^{\prime}\right.$ is positive $)$ can be observed, while fins make the rocket stabile. An influence of the boosters on the longitudinal stability is negligible.

In described case axis $\mathrm{y}$ and $\mathrm{y}_{\mathrm{M}}$ (of airflow coordinate system and model coordinate system) overlap. Thus there is no need to present $\mathrm{C}_{\mathrm{My}}$ and $\mathrm{C}_{\mathrm{Mpitch}}$ separately.

\subsection{Center of pressure location}

Figure 19 presents the location of center of pressure $\mathrm{X}_{\mathrm{CP}}$ as a function of angle of attack $\alpha^{6}$ for all investigated configurations, given as a distance from the center of pressure to the exhaust nozzle and calculated from equation:

$$
X_{C P}=\frac{C_{\text {Mpitch }}}{C_{N}} \cdot d+X_{C G}
$$

where:

$\mathrm{d}$ - diameter of the rocket body (reference dimension for the pitching moment coefficient); $\mathrm{X}_{\mathrm{CG}}$ - distance between exhaust nozzle and assumed center of gravity . 


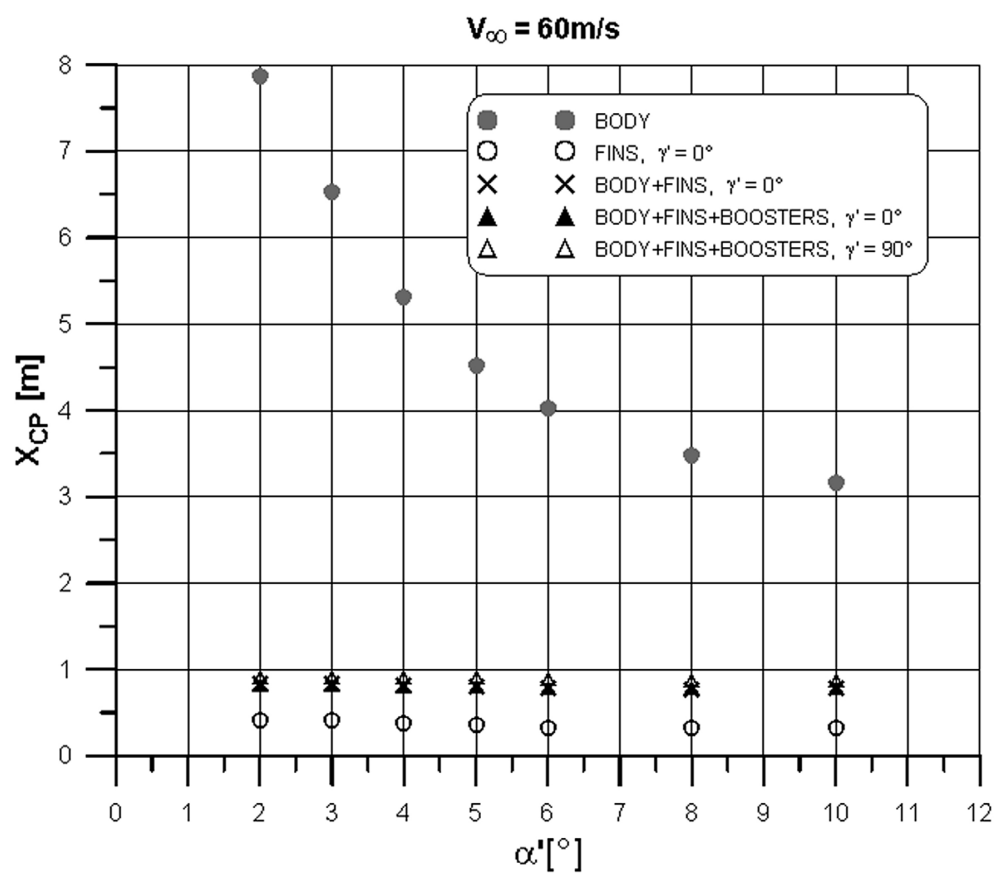

Figure 19. Center of pressure location.

It must be noted that the calculations have been performed only for angle of attack greater or equal to $2^{\circ}$. For the smaller angle of attack both $\mathrm{C}_{\mathrm{N}}$ and $\mathrm{C}_{\mathrm{Mpitch}}$ have small values, so the calculations could not be perform with satisfying accuracy.

One can be observed that the center of pressure for the isolated body is located in front of the rocket, which is compatible with literature information [20,21]. In this case, center of pressure shifts towards the nozzle with increment of angle of attack. For rocket with fins, both with or without boosters, the center of pressure lies about $0.8 \mathrm{~m}$ in front of the exhaust nozzle.

\subsection{Flow velocity measurement}

A flow velocity field around the front part of booster has been obtained using PIV method, for various angles of attack and for roll angle of 0 . The velocity field was found in the rocket's plane of symmetry. The field of view of PIV camera was located at the level of crown surface of the rocket and covered front part of the booster.

One of the most important conclusions of the velocity measurement above the booster increases, even up to $65 \mathrm{~m} / \mathrm{s}$ (Figure 16). According to Bernoulli's equation, it means that in this area the static pressure decreases, so one can expect an aerodynamic force which would cause a separation of front part of boosters from the body.

Results of the PIV measurement shows also that in front of the booster appears a zone of reduced speed, where the speed is equal $55 \mathrm{~m} / \mathrm{s}$ or less. Close to the booster's surface, the speed will be 
reduced to 0 (stagnation zone). It suggests that the drag of the booster is relatively large, which is confirmed by results of the aerodynamic loads measurement. It should be noted that the increased pressure in the stagnation zone results with separation of the front part of the booster.

The PIV measurements showed also that the boundary layer on the body can be observed only for lower angles of attack (Figure 20, left) - up to $5^{\circ}$. For higher angles of attack the airstream flows around the rocket.

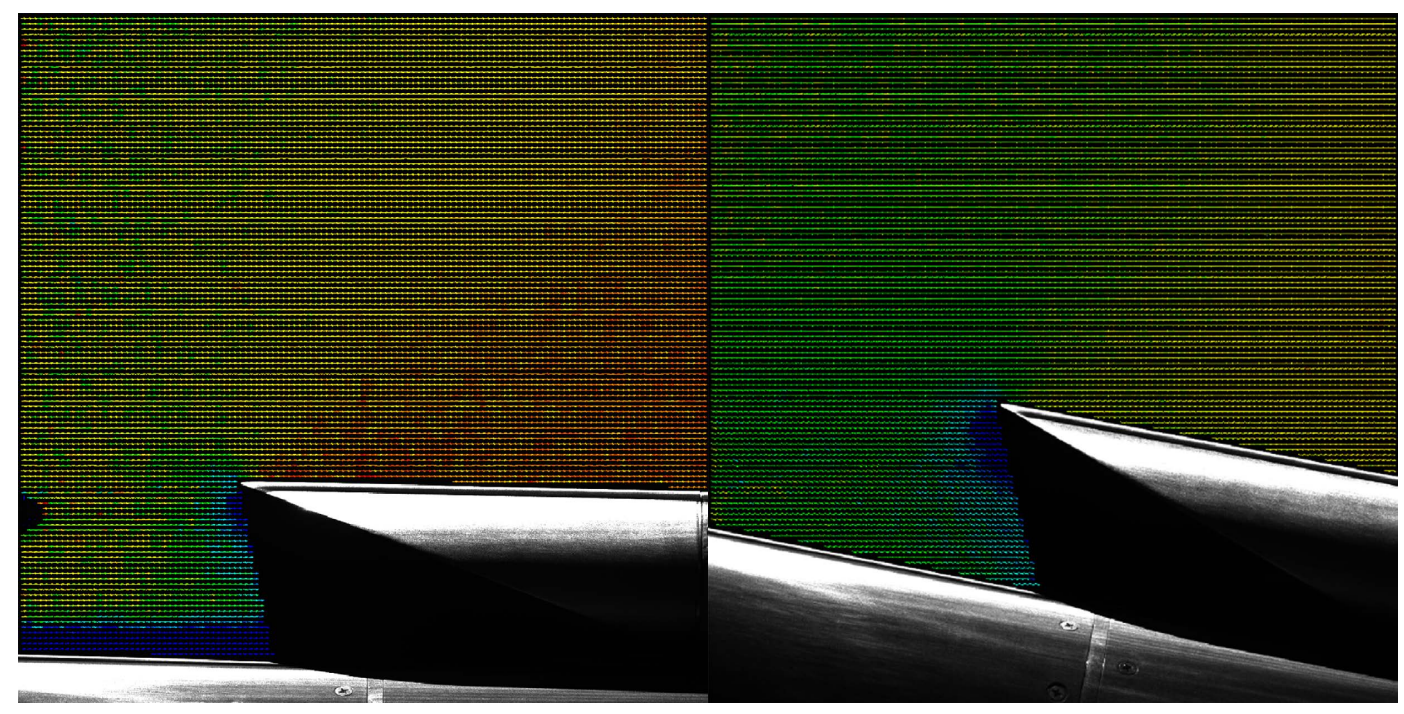

Vector color (min: 55 max: 65)

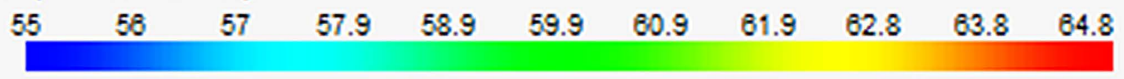

Figure 20. Flow velocity field for $\alpha^{6}=0.5$ (left) and for $\alpha^{6}=10^{\circ}$ (right).

\section{CONCLUSIONS}

The wind tunnel tests of the ERP have been conducted to obtain its aerodynamic characteristics, in various configurations, which will be used for calculations of stability and performance [22]. A flow velocity field around the front part of upper booster has been obtained using PIV, to assess a possibility of its separation caused by aerodynamic forces.

Results of the wind tunnel tests show i.a. that the boosters in investigated shape probably may be separated because of aerodynamic loads only. Further investigation of this aspect should be performed, to assess a strength of phenomenon found with the PIV measurements. The aerodynamic drag of the boosters is relatively high. However, it should not affect significantly the rocket's performance, because the boosters will be separated shortly after the take-off (its main purpose is to increase the acceleration), when the flight speed is low. It should be highlighted that the boosters' drag may support its separation. 
The correctness of results presented in the paper was assessed by comparison with analytical equations, given in [23], especially for isolated body and body\&boosters configurations. In this cases an aerodynamic interference is negligible. A comparison of these results is out of the scope of this paper.

Further study of the ERP are desireable, i.a. to extend our knowledge of the aerodynamic interference between boosters, fins and body. In our future research we intend to investigate a supersonic flow.

\section{ACKNOWLEDGMENT}

The authors would like to thank their colleagues from the wind tunnel staff for their contribution in the wind tunnel tests. The special acknowledgements are aimed at Mrs. Anna Suchożebrska (for the help with results postprocessing), Mr. Błażej Marciniak (for the photo-report during the tests) and Mr. Marek Kalski (for the controlling of wind tunnel and its stand). The authors would also appreciate the efforts and valuable help in translation of this paper from Kinga Wojno and Dmitriy Dorfman from Ohio State University.

\section{REFERENCES}

[1] Okninski, A., 2015, "An optimization of sounding rockets for microgravity research", 66th International Astronautical Congress, Jerusalem, IAC-15, A2, 5, 10, x30167.

[2] Walczewski, J., 1982, Polish sounding rocket program (Polskie rakiety badawcze), Wydawnictwa Komunikacji i Łączności, Warsaw.

[3] Wiśniowski, W. and Wolański, P., 2014, „Rola Instytutu Lotnictwa w badaniach kosmicznych” (Institute of Aviation Activities in the field of space research), Prace Instytutu Lotnictwa (Transactions of the Institute of Aviation), No. 234, pp. 9-16.

[4] Grzegorzewski, J., 1992, „Prace Instytutu Lotnictwa w dziedzinie techniki rakietowej” (Work of the Institute of Aviation Activities in the field of space research), Prace Instytutu Lotnictwa (Transactions of the Institute of Aviation), No. 131.

[5] Kaźmierski, J., Krawczyk, Z. and Nowak, K., 1997, „Technologia rakietowa i kosmiczna w Instytucie Lotnictwa" (Rocket and Space technology in the Institute of Aviation), Prace Instytutu Lotnictwa (Transactions of the Institute of Aviation), No. 151.

[6] Lewandowski, R., 1967, „Obciążenie aerodynamiczne niekierowanych rakiet balistycznych” (Aerodynamic loads of non-guided ballistic rockets), Prace Instytutu Lotnictwa (Transactions of the Institute of Aviation), No. 31, pp. 30-44.

[7] Kurow, W. and Dolzanski, J., 1964, Solid propellant rocket missile design, Military University of Technology Publisher, Warsaw.

[8] Lewandowski, R., 1968, „Wpływ czynników zakłócających na ruch niekierowanej rakiety meteorologicznej“ (Influence of the disturbances on the non-guided mereology rocket flight), Prace Instytutu Lotnictwa (Transactions of the Institute of Aviation), No. 36, pp. 3-15. 
[9] Lopez, D., Dominguez, D. and Gonzalo, J., 2013, „Impact of turbulence modelling on external supersonic flow field simulations in rocket aerodynamics“, International Journal of Computational Fluid Dynamics, Vol. 27, Nos. 8-10, pp. 332-341.

[10] Rasuo, B. and Bengin, A., 2015, “Aerodynamic shape optimization of guided missile based on wind tunnel testing and CFD simulation“, Thermal Scienc, (00), pp.184-184.

[11] Ocokolijić, G. and Rasuo, B., 2012, “Testing an Anti Tank Missile Model with Jet Simulation in the T-35 Subsonic Wind Tunnel“", Scientific Technical Review, No. 3-4(62), pp.14-20

[12] Bryson, H., Sültrop, H.P., Buchanan, G., Hann, C.E., Snowdon, M., Rao, A., Slee, A., Fanning, K., Wright, D., McVicar, J., Clark, B., Harris, G., Chen, X.Q., 2016, "Vertical Wind Tunnel for Prediction of Rocket Flight Dynamics“, Aerospace, No. 3(10).

[13] Ellis, S., 2017, "SLS Shocked During Wind Tunnel Testing to Better Understand Rocket's Transonic Behavior“", NASA website, https://www.nasa.gov/feature/langley/sls-shocked-duringwind-tunnel-testing-to-better-understand-rocket-s-transonic-behavior

[14] Marroquin, J. and Lemoine, P., 1992, "RESULTS OF WIND TUNNEL TESTS OF AN ASRM CONFIGURED 0.03 SCALE SPACE SHUTTLE INTEGRATED VEHICLE MODEL (47-OTS) IN THE AEDC 16-FOOT TRANSONIC WIND TUNNEL (IA613A), Space Shuttle aerothermodynamic data report“, DMS_DR-2548 NASA-CR-185, No. 696.

[15] "Aerodynamics Research Laboratory website", http://cntpolska.pl/zespol-aerodynamiki/laboratorium -aerodynamiki-stosowanej/?lang=en, access: 2018.01.19.

[16] Adrian, R., 2005, J., "Twenty Years of Particle Image Velocimetry“, Experiments in Fluids, No. 39, pp. 159-169.

[17] Stryczniewicz, W., 2012, "Development of Particle Image Velocimetry Algorithm", Problems of Mechatronics, No. 9, pp. 41-54.

[18] Surmacz, K., Ruchała, P. and Stryczniewicz, W., 2015, "Wind tunnel tests of the development and demise of Vortex Ring State of the rotor", Advances in Mechanics: Theoretical, Computational and Interdisciplinary Issues, Proceedings of the 3rd Polish Congress of Mechanics (PCM) and 21st International Conference on Computer Methods in Mechanics (CMM), CRC Press, Gdansk, pp. 8-11.

[19] Dziopa, Z., 2007, Mechanika lotu (Flight mechanics), Wydawnictwo Politechniki Świętokrzyskiej, Kielce.

[20] Fleeman, E., L., 2001, Tactical Missile Design, AIAA Education Series, American Institute of Aeronautics and Astronautics, Reston, USA.

[21] Barrowman, J., S. and Barrowman, J., A., 1966, "The Theoretical Prediction of the Center of Pressure", NARAM-8 R\&D Project, from the Apogee Components web site: www.ApogeeRockets.com

[22] Matyszewski, J., 2014, „Rozwój metod obliczeniowych do symulacji trajektorii lotu rakiet” (Development of rocket flight simulation methods), Prace Instytutu Lotnictwa (American Institute of Aeronautics and Astronautics), No. 1(234), pp. 90-103.

[23] Cieśliński, D., 2017, "Precise determination of static margins for unguided sounding rockets", presentation and conference paper, 66th IAC, IAC-15,E2,1,4,x30641, Jerusalem. 


\section{WPLYW SILNIKÓW POMOCNICZYCH I STATECZNIKÓW NA CHARAKTERYSTYKI AERODYNAMICZNE EKSPERYMENTALNEJ PLATFORMY RAKIETOWEJ}

\section{Streszczenie}

W artykule przedstawiono wyniki badań tunelowych Eksperymentalnej Platformy Rakietowej (EPR), powstającej w Instytucie Lotnictwa. EPR jest projektowana jako tania i łatwo dostępna platforma do eksperymentów w mikrograwitacji. Powstająca konstrukcja umożliwi wykonanie eksperymentów trwających do 150 sekund, na wysokości ok. $100 \mathrm{~km}$.

Model EPR w skali naturalnej został przebadany w tunelu aerodynamicznym T-3 w Instytucie Lotnictwa. Podczas badań zmierzono obciążenia aerodynamiczne działające na rakietę dla kątów natarcia do $10^{\circ}$ i różnych kątów obrotu wzdłuż osi podłużnej (do $90^{\circ}$, zależnie od konfiguracji). Badania wykonano dla trzech konfiguracji:

- korpus, bez stateczników i silników pomocniczych;

- ze statecznikami, bez silników pomocniczych;

- ze statecznikami i silnikami pomocniczymi.

Ponadto wykonano pomiary wektorowego pola prędkości przepływu wokół rakiety, używając metody anemometrii obrazowej PIV (Particle Image Velocimetry).

$\mathrm{Na}$ podstawie wyników badań tunelowych, określono wpływ stateczników i silników pomocniczych na charakterystyki aerodynamiczne. Wyniki pokazały m.in. duży wpływ silników pomocniczych na całkowity współczynnik oporu aerodynamicznego. W artykule przedstawiono również pewne wnioski dotyczące osiągów i stateczności rakiety.

Słowa kluczowe: aerodynamika rakiet, mechanika lotu rakiet, badania tunelowe, eksperymentalna, platforma, rakietowa, rakieta sondująca. 